\title{
ANALISIS SEKTOR KEUANGAN TERHADAP PERTUMBUHAN EKONOMI REGIONAL DI WILAYAH JAWA: PENDEKATAN MODEL LEVINE
}

\author{
Utami Baroroh \\ International Islamic University of Malaysia
}

\begin{abstract}
Financial Sector Analysis to The Regional Economic Growth in Java Region: Levine Model Approach. The objectives of this study are to analyze the influence of financial development to economic regional growth on Jawa region, using panel of province-level data on Jawa region for the period 2005-2010. The analysis method that used on this paper is panel data regression. The empirical results shown that financial asset and financial credit had a positive influence to economic regional growth on Jawa region, meanwhile third party fund had negative influence to economic regional growth on Jawa region. The other result shown that individual effect from fixed effect model showed that DKI Jakarta, Banten and East Jawa have potential as the centre of economic growth.
\end{abstract}

Keywords: regional economic growth, levine model, panel data regression.

\begin{abstract}
Abstrak. Analisis Sektor Keuangan Terhadap Pertumbuhan Ekonomi Regional di Wilayah Jawa: Pendekatan Model Levine. Tujuan dari kajian ini ialah untuk menganalisis pengaruh perkembangan keuangan terhadap pertumbuhan ekonomi regional di Wilayah Jawa, dengan menggunakan data di tingkat propinsi di wilayah Jawa mulai dari periode 2005-2010. Metode analisis yang dipergunakan dalam penelitian ini ialah regresi dengan data panel. Hasil empiris yang didapat menunjukkan bahwa aset keuangan dan kredit keuangan memiliki pengaruh positif terhadap pendapatan domestik regional bruto di wilayah Jawa, sedangkan dana pihak ketiga memiliki pengaruh yang negative terhadap pendapatan domestik regional bruto di wilayah Jawa. Hasil lain menunjukkan bahwa DKI Jakarta, Banten, dan Jawa Timur memiliki potensi sebagai pusat pertumbuhan ekonomi.
\end{abstract}

Kata Kunci: pertumbuhan ekonomi regional, model Levine, regresi data panel 


\section{PENDAHULUAN}

Pembangunan ekonomi di suatu negara sangat tergantung pada perkembangan dinamis dan kontribusi nyata dari sektor perbankan. Ketika sektor perbankan terpuruk perekonomian nasional juga ikut terpuruk. Demikian pula sebaliknya, ketika perekonomian mengalami stagnasi sektor perbankan juga terkena imbasnya dimana fungsi intermediasi tidak berjalan normal (Kiryanto, 2007).

Pasca krisis ekonomi 1997, Indonesia kembali menderegulasi kebijakan - kebijakan pada sektor keuangandalam hal pengawasan. Selain itu, juga terjadi perubahan kebijakan pemerintah daerah dengan diterbitkannya UU otonomi daerah tahun 2000 dan sudah diberlakukan sejak tahun 2001 sehingga mendorong pemerintah daerah untuk mengembangkan wilayahnya berdasarkan anggaran pemerintah daerah dan bukan angggaran yang berasal dari pemerintah pusat. Dengan diberlakukannya UU otonomi daerah maka setiap daerah harus membuat perencanaan investasi dan pengembangan daerahnya sehingga pertumbuhan ekonomi regional yang dicapai juga optimal. Salah satu sektor yang dapat mempengaruhi pertumbuhan ekonomi regional adalah sektor keuangan.

Sektor keuangan sendiri memegang peranan yang sangat penting dalam memicu pertumbuhan ekonomi suatu daerah. Menurut Bank Dunia, sektor keuangan yang semakin berkembang diyakini dapat mendorong pertumbuhan ekonomi, menurunkan kemiskinan, dan meredam volatilitas ekonomi makro. Namun rekomendasi tersebut masih menimbulkan perdebatan baik secara teori maupun secara empiris. Ada dua hal pokok yang masih diperdebatkan terkait perkembangan sektor keuangan, pertumbuhan ekonomi dan volatilitas ekonomi makro.

Pertama, perdebatan mengenai apakah perkembangan sektor keuangan yang mendorong pertumbuhan ekonomi (finance - led growth) atau pertumbuhan ekonomi yang mendorong perkembangan sektor keuangan (growth - led finance) (Levine, 1997; Patrick, 2000). Kedua, perdebatan mengenai hubungan antara perkembangan sektor keuangan dan volatilitas ekonomi makro. Perdebatan kedua terfokus pada permasalahan apakah sektor 
keuangan yang semakin berkembang akan menyebabkan volatilitas ekonomi makro. Tujuan kebijakan ekonomi makro adalah pertumbuhan ekonomi yang tinggi dan berkesinambungan, tingkat pengangguran yang rendah, fluktuasi pertumbuhan ekonomi dan pengangguran yang rendah (meredam siklus bisnis), dan tingkat inflasi yang rendah. Tujuan-tujuan tersebut dapat dicapai melalui berbagai kebijakan Bank Dunia (2001) yang menekankan pentingnya sektor keuangan untuk mencapai tujuan tersebut karena sektor keuangan dapat mendorong pertumbuhan ekonomi, menurunkan kemiskinan, dan meredam volatilitas ekonomi makro. Oleh karena itu, Bank Dunia menyarankan pentingnya kebijakan yang mendorong perkembangan sektor keuangan di berbagai negara di dunia.

Atas dasar itu semua, pengembangan sistem keuanganyang mampu menjalankan fungsi-fungsinya secara efektif dan memiliki ketahananyang tinggi merupakan langkah yang sangat strategis dalam mendukung percepatan pemulihan ekonomi Indonesia dan menjaga kestabilan makroekonomi. Berkaitan dengan itu, salah satu aspek yang sering diperdebatkan di dalam pengembangan sistem keuangan adalah menurut teori endogenous growth (Solow), pertumbuhan ekonomi atau output di dorong oleh physical maupun human capital yang diakselerasi oleh variabel produktitas.

Pembangunan ekonomi tak dapat lepas dari pertumbuhan ekonomi (economic growth), pembangunan ekonomi mendorong pertumbuhan ekonomi, dan sebaliknya, pertumbuhan ekonomi memperlancar proses pembangunan ekonomi.Pertumbuhan ekonomi adalah suatu proses kenaikan pendapatan total dan pendapatan perkapita dengan memperhitungkan adanya pertambahan penduduk dan disertai dengan perubahan fundamental dalam struktur ekonomi suatu negara.

Pembangunan ekonomi mengandung arti yang lebih luas dan mencakup perubahan pada tata susunan ekonomi masyarakat secara menyeluruh. Menurut Sadono (2007:3), pembangunan ekonomi adalah serangkaian usaha dalam suatu perekonomian untuk mengembangkan kegiatan ekonominya sehingga infrastruktur lebih banyak tersedia, perusahaan semakin banyak dan semakin berkembang, taraf pendidikan semakin tinggi dan teknologi semakin 
meningkat. Menurut Patrick (1966) terdapat dua kemungkinan hubungan kausalitas antara pembangunan sektor keuangan dan pertumbuhan ekonomi, yaitu: pertama, demand-following, bahwa rendahnya pertumbuhan sektor keuangan adalah manifestasi kurangnya permintaan akan jasa finansial. Kedua, supply-leading, bahwa sektor keuangan mendahului dan mendorong pertumbuhan sektor riil. Demand-following adalah fenomena ketika pembentukan institusi finansial modern, aset dan liabilitas, dan berbagai jasa keuangan adalah sebagai respon dari meningkatnya permintaan jasa keuangan oleh para investor dan penabung dalam sektor riil. Pada saat perekonomian riil tumbuh maka permintaan akan jasa keuangan juga akan bertambah, dengan semakin banyaknya jasa keuangan yang digunakan maka perkembangan sektor keuangan juga akan menjadi positif.

Supply-leading hypothesis berarti bahwa pembangunan institusi dan pasar keuangan akan meningkatkan penawaran jasa keuangan (terutama permintaan jasa oleh para pengusaha dan investor) yang akan mengarah pada pertumbuhan ekonomi riil. Supply-leading mempunyai dua fungsi, yaitu untuk mentransfer sumberdaya dari sektor tradisional menuju sektor industri, dan untuk mendorong respon para pengusaha dalam sektor industri. Lembaga intermediasi yang mentransfer sumberdaya dari sektor tradisional (melalui peningkatan kesejahteraan dan tabungan dari sektor ini untuk dijadikan deposito atau dengan penciptaan kredit) sesuai dengan konsep Schumpeter tentang inovasi keuangan (Maski, 2010).

Berbagai studi komparasi lintas negara serta analisis pada level industri dan perusahaan menyimpulkan bahwa sistem keuangan memainkan peran vital dalam mendorong pertumbuhan ekonomi. Literatur menunjukkan bahwa perkembangan sistem keuangan mempengaruhi tingkat tabungan, investasi, inovasi teknologi, dan pertumbuhan ekonomi jangka panjang di suatu negara. Berbagai studi empirik bahkan membuktikan bahwa perkembangan sistem keuangan mampu memprediksi perkembangan ekonomi ke depan. Berbagai penelitian menyimpulkan bahwa negara-negara yang berhasil mengembangkan sistem keuangan yang relatif lebih maju dan berfungsi dengan baik adalah negara-negara yang kemudian menjadi pemimpin perekonomian 
dunia pada masanya. Peran vital sistem keuangan dalam pembangunan ekonomi muncul karena berbeda dengan kondisi ideal yang menjadi landasan teori ekonomi Neoklasik dalam realitas sehari-hari para pelaku ekonomi selalu dihadapkan pada biaya informasi dan biaya transaksi keuangan yang tinggi. Keberadaan dua jenis biaya tersebut mengakibatkan transaksi langsung antara pihak penabung/pemilik dana dan pihak yang membutuhkan dana tidak berjalan optimal. Akibatnya, berbagai kesempatan investasi dan konsumsi yang seharusnya dapat mendorong percepatan pertumbuhan ekonomi menjadi tidak dapat direalisasikan.

Levine (1997) membagi fungsi utama sistem keuangan tersebut ke dalam lima fungsi dasar, yaitu: memobilisasi tabungan, mengalokasikan sumber daya, memantau para manajer dan melaksanakan pengawasan perusahaan, memfasilitasi perdagangan, lindung-nilai, diversifikasi, dan penggabungan risiko, dan memfasilitasi transaksi barang dan jasa agar lebih efisien.

Masing-masing fungsi sistem keuangan tersebut dapat mempengaruhi pertumbuhan ekonomi melalui dua jalur, yaitu: jalur akumulasi modal (modal fisik dan modal manusia) dan jalur inovasi teknologi. Kedua jalur tersebut merupakan dua sumber utama pertumbuhan ekonomi jangka panjang yang berkembang di dalam literatur teori pertumbuhan ekonomi.

Sistem keuangan mempengaruhi kedua sumber pertumbuhan dengan cara mempengaruhi tingkat tabungan (sisi penawaran dana) dan dengan merealokasikan tabungan ke dalam berbagai alternatif investasi (sisi permintaan dana), baik investasi modal fisik, investasi sumber daya manusia, maupun investasi teknologi. Semakin baik sistem keuangan dalam menjalankan fungsi-fungsi dasarnya, semakin besar kontribusi sistem keuangan dalam mendukung pertumbuhan ekonomi.Tanpa aksespada berbagai sumberdana (investor), banyak kegiatan usaha yang hanya mampu berproduksi dalam volume relatif kecil sehingga tidak efisien. Sistem keuangan dapat menciptakan berbagai instrumen yang dapat digunakan untuk memobilisasi dana dalam jumlah kecil tetapi banyak.

Hal ini dikemukakan oleh Merton dan Bodie (1995) sebagaimana dikutip oleh Levine (1997). Merton (1991) menyebutkan enam fungsi sistem 
keuangan yang pada prinsipnya sama dengan yang diajukan Levine (1997), yaitu: menyediakan fasilitas transaksi pembayaran, mengumpulkan dana, menyediakan mekanisme penyaluran dana antar ruang dan antar waktu, melakukan manajemen risiko, memberikan informasi harga, dan mengatasi masalah ketimpangan informasi (asymmetric information). Sementara itu, hipotesis terkait dengan fungsi lembaga keuangan sebenarnyajauh sebelumnya dipelopori oleh Joseph Schumpter (1911) yang menyatakan bahwa lembaga keuangan memberikan kontribusi positif bagi perekonomian melalui 5 perannya yaitu: memobilisasi dana, mengevaluasi proyek, mengelola risiko, mengawasi para manajer, dan fasilitasi transaksi.

Distribusi aset mungkin perlu mendapatkan perhatian yang lebih daripada distribusi pendapatan. Pada negara-negara industri, di mana hambatan ke pasar kredit relatif lebih kecil daripada di negara sedang berkembang (NSB) nilai distribusi aset (yang diukur dengan warisan kekayaan) merupakan variabel kunci untuk mengukur kemampuan individu memulai suatu usaha dan meningkatkan distribusi pendapatannya (Bardhan et. al, 1998). Di China ditemukan hubungan yang negatif dan signifikan antara distribusi asset lokal dengan pertumbuhan konsumsi individual (Ravallion, 1997).

Untuk memaksimumkan keuntungannya, sebuah bank harus terus menerus mencari kemungkinan imbal hasil tertinggi atas kredit dan surat berharga, mengurangi risiko dan mencukupi kebutuhan likuiditas dengan memiliki aset yang likuid. Bank-bank berupaya untuk memenuhi ketiga tujuan ini dengan empat cara dasar.

Pertama, bank berupaya menemukan peminjam yang akan membayar suku bunga tinggi dan kecil kemungkinan gagal bayar. Mereka mencari usaha pemberian pinjaman dengan mengiklankan suku bunga pinjamannya dan dengan mendekati perusahaan secara langsung untuk menawarkan pinjaman. Kedua, Bank berupaya untuk membeli surat berharga dengan imbal hasil tinggi dan risiko rendah. Ketiga, dalam mengelola asetnya, bank harus mencapai risiko yang lebih rendah dengan cara mendiversifikasi. Mereka mencapainya dengan membeli beberapa macam asset dan menyetujui beberapa jenis kredit kepada 
berbagai nasabah. Terakhir, bank harus mengelola likuiditas dari asetnya sedemikian rupa sehingga dapat memenuhi giro wajib minimum tanpa menanggung beban yang besar. Dua aset dari neraca bank sentral penting karena dua alasan. Pertama, perubahan dalam aset mendorong perubahan cadangan dan mengakibatkan perubahan uang beredar. Kedua, karena aset-aset ini (surat utang pemerintah dan discount loan) menerima pendapatan bunga, sedangkan kewajiban tidak menghasilkan bunga.

Bencivenga dan Smith (1991) mengembangkan model dimana individu menghadapi ketidakpastian akan kebutuhan likuiditasnya di masa depan. Individu dapat memilih investasi pada aset yang likuid dan tidak berisiko, namun mempunyai tingkat produktivitas yang rendah, dan atau memilih investasi pada aset yang tidak likuid dan berisiko, namun mempunyai tingkat produktifitas yang rendah, dan atau memilih investasi pada aset yang tidak likuid dan berisiko, namun mempunyai tingkat produktifitas yang tinggi. Berdasarkan hal tersebut, sektor keuangan dapat mendorong pertumbuhan ekonomi melalui penyaluran tabungan ke proyek-proyek yang mempunyai tingkat produktifitas yang tinggi dan sekaligus dapat menurunkan risiko likuiditas yang dihadapi oleh individu.

Selain menurunkan risiko likuiditas, sektor keuangan juga dapat menurunkan risiko investasi. Ketika individu tidak menyukai risiko, maka investasi yang berisiko akan menwarakan pendapatan yang tinggi, sedangkan investasi yang kurang berisiko akan menawarkan pendapatan yang rendah. Sektor keuangan yang memiliki kemampuan dalam melakukan diversifikasi terhadap risiko, selain dapat menurunkan risiko yang dihadapi oleh masyarakat juga akan dapat mempengaruhi keinginan masyarakat untuk menabung.

Salah satu kegiatan industri perbankan adalah pemberian kredit. Menurut Siamat (2004), proporsi pendapatan terbesar bank berasal dari pendapatan bunga kredit yang disalurkan. Sedangkan jumlah kredit yang disalurkan tersebut didanai oleh beberapa sumber yaitu modal sendiri, pinjaman dari lembaga lain, dan pihak ketiga atau masyarakat. Menurut Kasmir (2004), dana pihak ketiga memiliki kontribusi terbesar dari beberapa sumber dana tersebut sehingga jumlah dana pihak ketiga yang berhasil dihimpun oleh 
suatu bank akan mempengaruhi kemampuannya dalam menyalurkan kredit. Kredit diberikan kepada para debitur yang telah memenuhi syarat-syarat yang tercantum dalam perjanjian yang dilakukan antara pihak debitur dengan pihak bank. Dana yang dihimpun dari masyarakat ternyata merupakan sumber dana terbesar yang paling diandalkan oleh bank dan bisa mencapai 80\%-90\% dari seluruh dana yang dikelola bank (Dendawijaya 2005:35). Dana dari masyarakat yang sering disebut dengan dana pihak ketiga terdiri atas beberapa jenis yaitu Giro (Demand Deposit), Tabungan (Saving Deposit) dan Deposito (time deposit).

Berdasarkan hipotesis Keynes tingkat pendapatan nasional berpengaruh positif terhadap tabungan nasional (dalam Darmawan, 2006). Penelitian ini menemukan bahwa pendapatan nasional perkapita mempunyai efek positif terhadap tingkat tabungan nasional. Sementara itu studi cross-sectional komprehensif pertama kali dilakukan oleh Simon Kuznet mengenai hubungan antara tabungan dan pendapatan per kapita pada tahun 1960.

Menurut Keynes pengaruh tingkat bunga terhadap tabungan nasional sangat kompleks serta banyak kemungkinan yang akan terjadi. Di samping itu juga membutuhkan lag yang cukup lama (Molho, 1986). Arrieta (1988) dalam studinya menyimpulkan bahwa tingkat bunga berpengaruh positif terhadap tabungan nasional. Muradoglu dan Taskin (1996) dalam penelitiannya menemukan bahwa efek tingkat bunga dapat dijelaskan dari keputusan konsumsi intertemporer. Peningkatan pengembalian tabungan akan meningkatkan tabungan tetapi efek pendapatan riil terhadap tingkat pengembalian mengakibatkan tabungan menurun.

Pengertian kredit menurut Undang-Undang Republik Indonesia Nomor 1998 dalam pasal 1, kredit adalah penyediaan uang atau tagihan yang dapat dipersamakan dengan itu, berdasarkan persetujuan atau kesepakatan pinjammeminjam antara bank dengan pihak lain yang mewajibkan pihak peminjam untuk melunasi utangnya setelah jangka waktu tertentu dengan pemberian bunga. Dalam kehidupan perekonomian yang modern, bank memegang peranan sangat penting. Oleh karena itu, organisasi-organisasi bank selalu diikutsertakan dalam menentukan kebijakan di bidang moneter, pengawasan devisa, dan lain-lain. 


\section{METODE}

Penelitian ini menggunakan data sekunder dengan analisis panel data. Data panel adalah gabungan dari data cross section 6 propinsi di Pulau Jawa dan time series dengan data tahunan dari tahun 2005 - 2010. Data yang digunakan meliputi produk domestik regional bruto (PDRB), aset bank umum, dana pihak ketiga bank umum dan kredit yang disalurkan perbankan pada masing-masing provinsi di Pulau Jawa. Data dalam penelitian ini diambil dari berbagai sumber seperti laporan tahunan BI, Propinsi dalam angka, Statistik Perbankan Indonesia (SPI), dan Statistik Keuangan Pemerintah Daerah dan SEKDA (Statistik Ekonomi Keuangan Daerah).

Pemilihan analisis data panel dilakukan karena beberapa kelebihan yang dimilikinya antara lain yaitu dapat memberikan data yang lebih informatif, mengurangi kolinearitas antar variabel, derajat kebebasan yang lebih banyak dan model yang lebih efisien (Baltagi, 2001 p:235).

Menurut Gujarati (2003) penggunaan data panel mampu memberikan banyak keunggulan secara statistik maupun secara teori ekonomi, antara lain: Pertama, data panel mampu memperhitungkan heterogenitas individu secara eksplisit dengan mengizinkan variabel spesifik individu sehingga membuat data panel dapat digunakan untuk menguji dan membangun model perilaku yang lebih kompleks. Kedua, jika efek spesifik adalah signifikan berkorelasi dengan variabel penjelas lainnya, maka penggunaan data panel akan mengurangi masalah omitted-variables secara substansial.

Ketiga, data panel mendasarkan diri pada observasi cross section yang berulang-ulang sehingga metode data panel cocok digunakan untuk study of dynamic adjustment. Keempat, tingginya jumlah observasi berimplikasi pada data yang lebih informatif, lebih variatif, kolinearitas antar variabel yang semakin berkurang, dan peningkatan derajat kebebasan (degree of freedom) sehingga dapat diperoleh hasil estimasi yang lebih efisien.

Keunggulan-keunggulan tersebut diatas memiliki implikasi pada tidak diperlukan pengujian asumsi klasik dalam model data panel, sesuai apa yang ada dalam beberapa literatur yang digunakan dalam penelitian ini (Maddala, 1998; Pindyck dan Rubinfield, 1991; dan Gujarati, 2003). Estimasi data panel 
dengan model regresi dilakukan dengan tiga teknik yaitu menggunakan pendekatan OLS biasa (Pooled Least Square), pendekatan efek tetap fixed Effect Model (FEM)dan pendekatan efek acak (random effects model (REM).

Model ekonometri yang dipergunakan adalah model yang dirumuskan oleh Levine (2000) yaitu:

$$
\text { Growth }_{\mathrm{i}}=\aleph_{0}+ß_{1}\left(\text { (inance }_{\mathrm{i}}+\aleph_{2}(\text { Conditioning set })_{\mathrm{i}}+\mathrm{e}_{\mathrm{t}}(3.1)\right.
$$

Sehingga bentuk model yang akan digunakan adalah :

$$
G_{i, t}=\beta_{0 i, t}+\beta_{1} A_{i, t}+\beta_{2} F_{i, t}+\beta_{3} C_{i, t}+e_{t}(3.2)
$$

Dimana :

$\mathrm{G}_{\mathrm{i}, \mathrm{t}}=$ pertumbuhan ekonomi provinsi i tahun $\mathrm{i}$

$\beta_{\mathrm{i}, \mathrm{t}}=$ konstanta/intersep

$ß=$ koefisien regresi

$\mathrm{A}_{\mathrm{i}, \mathrm{t}}=$ Aset bank umum pada provinsi i tahun $\mathrm{t}$

$\mathrm{F}_{\mathrm{i}, \mathrm{t}}=$ Dana pihak ketiga bank umum pada provinsi $\mathrm{i}$ tahun $\mathrm{t}$

$\mathrm{C}_{\mathrm{i}, \mathrm{t}}=$ Kredit yang disalurkan perbankan pada provinsi i tahun $\mathrm{t}$

$\mathrm{e}_{\mathrm{t}}=$ error term

$\mathrm{i}, \mathrm{t}=$ provinsi ke- dan periode waktu/tahun ke-

Banyaknya unit waktu di setiap unit individu inilah yang mencirikan apakah data panel tersebut seimbang atau tidak. Jika tiap-tiap unit individu diobservasi dalam waktu yang sama maka data panel dikatakan seimbang (balanced panel data). Sedangkan jika tidak semua unit individu diobservasi pada waktu yang sama atau bisa juga disebabkan adanya data yang hilang dalam suatu unit individu, maka data panel dikatakan tidak seimbang (unbalanced panel data).

Untuk mendapat model yang estimasi yang tepat dilakukan pengujian model. Ada 2 tahap dalam memilih metode estimasi dalam data panel. Pertama, membandingkan PLS dengan FEM dengan melakukan uji F-test. Jika hasil menunjukkan model PLS yang diterima, maka model PLS-lah yang akan dianalisa. Tapi jika model FEM yang diterima, maka tahap kedua dijalankan, yakni melakukan perbandingan lagi dengan model REM. Setelah itu dilakukan pengujian dengan Haussman test untuk menentukan model mana yang akan dipakai, apakah FEM atau REM. 


\section{PEMBAHASAN}

Sebelum melakukan analisis dengan data panel, terlebih dahulu dilakukan uji normalitas terhadap seluruh data. Hasil dari uji normalitas menunjukkan bahwa seluruh data variabel penelitian berdistribusi normal sehingga dapat dilanjutkan ke tahap berikutnya. Setelah dilakukan uji normalitas, selanjutnya dilakukan estimasi dengan pendekatan Pooled Least Squares (PLS) dan diikuti estimasi dengan pendekatan fixed effect model (FEM).

Hasil penelitian dengan model PLS menunjukkan bahwa sebagian besar variable-variabel bebas berpengaruh secara signifikan terhadap pertumbuhan ekonomi regional di Pulau Jawa.Variabel aset signifikan pada tingkat kepercayaan 99 persen, demikian juga denganvariable kredit dan DPK. Nilai Rsquared menunjukkan model yang digunakan mampu menjelaskan fenomena sebesar 89,31persen.

Hasil estimasi model FEM yang terlihat menunjukkan bahwa semua variable bebas berpengaruh secara signifikan terhadap pertumbuhan ekonomi regional di Pulau Jawa. Variabel asset, kredit dan DPK signifikan pada tingkat kepercayaan alpha $=5 \%$. Nilai $R$-squared menunjukkan model yang digunakan mampu menjelaskan fenomena sebesar 71,81persen.

Untuk lebih memastikan model mana yang paling tepat pada model penelitian, dilakukan Uji Chow untuk membandingkan model PLS vs FEM dan Uji Hausman untuk membandingkan model FEM vs REM. Berdasarkan hasil uji Chow diperoleh nilai probability dari F statistik dengan d.f $(5,27) 0.00005$ yang berarti menolak hipotesis untuk menggunakan Pooled Least Squared dan menerima hipotesis untuk menerima fixed effect model. Maka berdasarkan hasil uji tersebut model yang digunakan adalah fixed effect model.

Setelah dilakukan uji Chow dan menghasilkan model efek tetap, selanjutnya dilakukan estimasi model efek acak (random effct model). Hasil estimasi random effct model (REM) menunjukkan bahwa sebagian besar variable-variabel bebas tidak berpengaruh secara signifikan terhadap pertumbuhan ekonomi regional di Pulau Jawa. Tingkat signifikan suatu variabel dapat dilihat pada nilai probabilitasnya, bila lebih besar dari 0.05 maka variable tersebut tidak signifikan pada tingkat kepercayaan 5\%, dan hasil menunjukkan 
semua variable bebas bernilai lebih besar dari 0.05. Nilai Adjusted R-squared juga menunjukkan model yang digunakan hanya mampu menjelaskan fenomena sebesar 8,95 persen.

Setelah melakukan estimasi random effect model selanjutnya dilakukan uji model antara estimasi FEM dan estimasi REM dengan uji Hausman. Uji Hausman memberikan penilaian dengan menggunakan chi-square statistik. Berdasarkan hasil uji Hausman yang dilakukan,didapatkan Chi-Sq Statistik sebesar 0.220913 dengan probabilitas 0.9417 pada d.f 3, dengan menggunakan chi-tabel diperoleh nilai sebesar 0.58. Hasil tes menyatakan bahwa chi statistik lebih besar dari pada chi-tabel, sehingga dapat disimpulkan bahwa H0 ditolak dan model terbaik yang dapat digunakan untuk model penelitian adalah Fixed Effect Model. Menurut Nachrowi dan Usman (2006), kelebihan dari fixed effect model adalah model dapat membedakan efek individual serta tidak perlu mengasumsikan bahwa komponen error tidak berkorelasi dengan variable bebas.

Berdasarkan regresi model PLS, FEM dan REM serta uji model yang dilakukan seperti uji Chow dan Uji Hausman semua menunjukkan hasil model terbaik adalah model FEM. Hasil estimasi menunjukkan bahwa semua variabel independen berpengaruh terhadap variabel dependen. Variabel Aset berpengaruh signifikan terhadap pertumbuhan ekonomi regional pulau Jawa dan memiliki hubungan positif dengan nilai koefisien adalah sebesar 0,34 . Hal ini mengartikan bahwa apabila jumlah aset perbankan naik sebesar satu persen maka jumlah pertumbuhan ekonomi regional Pulau jawa akan meningkat pula sebesar 0,34 persen.

Variabel kredit juga menunjukkan pengaruh yang positif dengan nilai koefisien 0,072. Nilai koefisien menunjukkan bahwa apabila jumlah kredit perbankan naik sebesar satu persen maka jumlah pertumbuhan ekonomi regional Pulau Jawa akan meningkat sebesar 0,072 persen. Hasil ini konsisten dengan teori yang dikemukakan oleh Levine (1997), King and Levine (1993) dan Edward S.Shan (1973).

Untuk variabel dana pihak ketiga juga menunjukkan pengaruh yang signifikan terhadap pertumbuhan ekonomi regional Pulau Jawa tetapi 
berhubungan negatif. Nilai variabel dana pihak ketiga adalah 0,076 yang dapat diartikan bahwa bila terjadi penurunan dana pihak ketiga sebesar satu persen maka pertumbuhan ekonomi regional Pulau Jawa akan meningkat sebesar 0,076 persen. Hasil penelitian ini berbeda dengan teori yang ada dikarenakan kebijakan penempatan DPK turut memicu pertumbuhan DPK tetapi hal ini akan berkontribusi terhadap peningkatan tabungan valas yang dapat berakibat menurunkan pertumbuhan ekonomi.

Berdasarkan hasil olahan data juga menunjukkan bahwa variabel sektor finansial berpengaruh terhadap pertumbuhan ekonomi regional Pulau Jawa secara bersama-sama pada tingkat kepercayaan 99\%. Hal ini ditunjukkan dengan nilai probabilitas Uji F sebesar 0,000009. Sedangkan koefisien determinasi dalam penelitian ini adalah sebesar 0.718072 atau 71, 81\%. Hal ini mengindikasikan bahwa variabel sektor finansial yang terdiri dari aset, kredit dan dana pihak ketiga mampu menjelaskan variabel pertumbuhan ekonomi regional di Pulau Jawa sebesar 71,81\% dan sisanya sebesar 28,19\% dijelaskan oleh variabel lain yang tidak dimasukkan ke dalam model estimasi.

Efek individu yang dihasilkan oleh fixed effect merupakan gambaran heterogenitas setiap propinsi. Heterogenitas antar propinsi yang dihasilkan mencerminkan adanya faktor-faktor atau variable lain yang dimiliki oleh suatu propinsi tetapi tidak dimiliki oleh propinsi lain. Dengan kata lain propinsi tersebut memiliki karakteristik masing-masing yang tercermin dalam variabel lain (diluar variabel bebas dalam model). Apabila diasumsikan variabel bebas tidak berubah maka determinan dari pertumbuhan ekonomi regional pulau Jawa hanya akan tergantung dari efek individu.

Berdasarkan perhitungan dapat terlihat bahwa masing-masing provinsi memiliki tingkat koefisien fixed effect yang berbeda-beda antara satu sama lain. Keadaan tersebut menjelaskan bahwa variable aset perbankan, kredit dan dana pihak ketiga memiliki tingkat pengaruh yang berbeda terhadap pertumbuhan ekonomi regional di masing-masing provinsi. Besar kecilnya nilai intersep tersebut memberikan gambaran mengenai daerah-daerah yang berpotensi sebagai pusat pertumbuhan ekonomi. Berdasarkan hasil estimasi 3 provinsi dengan nilai intersep terbesar yaitu DKI Jakarta, Banten dan Jawa Timur dan 3 
propinsi dengan nilai intersep terkecil yaitu Jawa Tengah, DIY dan Jawa Barat. Dengan demikian 3 propinsi terbesar tersebut merupakan daerah potensial pertumbuhan ekonomi sementara propinsi dengan intersep terkecil merupakan propinsi yang kurang potensial sebagai tujuan pertumbuhan.

Hasil yang didapat memperlihatkan nilai intersep pada propinsi Banten adalah 9,223383 yang dapat diartikan bila terdapat perubahan pada sektor finansial maupun waktu, maka Propinsi Banten akan mendapatkan pengaruh individu terhadap PDRB sebesar 9,223383\%. DKI Jakarta sebagai pusat pemerintah sekaligus pusat bisnis mempunyai intersep sebesar 12,166233 dan tertinggi di Pulau Jawa. Hal ini semakin membuktikan bahwa propinsi DKI Jakarta memang pusat pertumbuhan ekonomi. Selain itu nilai intersep dapat ditafsirkan bahwa bila terjadi perubahan pada sektor finansial maupun waktu, maka propinsi DKI Jakarta akan mendapat pengaruh individu terhadap PDRB sebesar $12,166233 \%$.

Hasil pengujian pada propinsi Jawa Barat menunjukkan nilai 6,290249 dan Jawa Barat termasuk daerah yang kurang potensial sebagai tujuan pertumbuhan. Propinsi Jawa Barat menjadi kurang kompetitif jika dibandingkan dengan propinsi Banten. Begitu pula dengan propinsi Jawa Tengah. Jawa Tengah adalah propinsi yang paling tidak potensial sebagai tujuan pertumbuhan bila dibandingkan dengan 5 propinsi lainnya. Pengaruh individu pada propinsi Jawa Tengah hanya sebesar 4,578999\%.

Propinsi DIY masih lebih baik bila dibandingkan dengan Jawa Tengah karena hasil dari efek individu berada di atas propinsi Jawa Tengah. Nilai intersep utuk provinsi DIY adalah sebesar 5,173155 persen sehingga jika terjadi perubahan sektor finansial maka propinsi DIY hanya akan mendapat pengaruh individu sebesar 5,173155 persen. Sedangkan Propinsi Jawa Timur termasuk dalam propinsi yang merupakan tujuan pertumbuhan ekonomi. Hal ini terlihat dari efek individu yang bernilai 7,033417 persen masih dibawah propinsi DKI Jakarta dan Banten

\section{SIMPULAN}

Berdasarkan hasil analisis yang dilakukan dalam penelitian ini maka penulis dapat menyimpulkan sebagai berikut variabel aset perbankan, kredit 
perbankan dan dana pihak ketiga secara parsial sangat mempengaruhi pertumbuhan ekonomi regional di Pulau Jawa dan hal ini sesuai dengan teori yang ada dan penelitian yang banyak dilakukan diantaranya oleh Levine (1997), Erdogen, Esen and Umit Ozlaze (2005). Variabel aset dan kredit menunjukkan hubungan positif terhadap pertumbuhan ekonomi.

Hal ini menandakan kuatnya pengaruh bank terhadap aktivitas perekonomian dan mengindikasikan kredit yang tersalur terwujud dalam akumulasi modal fisik. Untuk variabel dana pihak ketiga menunjukkan hubungan negatif yang berarti terjadinya pengalihan dana dari pelaku ekonomi. Terintegrasinya pasar modal dan pasar perbankan menyebabkan pelaku ekonomi bebas melakukan pengalihan dana sehingga dana yang terhimpun tidak terwujud dalam akumulasi modal fisik atau investasi.

Hasil penelitian menunjukkan bahwa semua variabel independen secara simultan mempengaruhi variabel bebas. Sedangkan nilai koefisien determinasi dari penelitian ini adalah 0,718. Dengan kata lain, bahwa variabel independen mampu menjelaskan 71,81 persen terhadap variabel bebas sedangkan 28,19 persen dipengaruhi oleh variabel lain yang tidak diteliti seperti jumlah uang beredar, tingkat suku bunga dan lain sebagainya. Selain itu hasil estimasi menunjukkan efek individu yang menggambarkan heterogenitas setiap propinsi. Hasil estimasi menunjukkan bahwa propinsi DKI Jakarta, Banten dan Jawa Timur merupakan daerah yang berpotensi sebagai pusat pertumbuhan ekonomi.

\section{PUSTAKA ACUAN}

Bardhan, P, et.al. 1998, Wealth Inequality, Wealth Constrains and Economic Performance. University of Massachusetts Amherst.

Benchivenga, V.R \& Smith, B.D. 1991. Financial Intermediations and Endogenous Growth. Review of Economics Studies, pp 195 - 209.

Darmawan, K. 2004. Analisis Rasio-rasio Bank. Info Bank. Juli, 18-21

Dendawijaya, L. 2005. Manajemen Perbankan. Jakarta: Ghalia Indonesia Gujarati, D. 2007. Basic Econometrics, Fourth edition. New York: McGraw Hill. Kasmir. 2008. Bank dan Lembaga Keuangan Lainnya. Jakarta :PT. Raja Grafindo Persada 
King, R. G \& Levine, R. 1993. Finance and Growth: Schumpeter Might Be Right. Quarterly Journal of Economics 108(3), pp. 717-37.

Kiryanto, R. 2007. Langkah Terobosan Mendorong Ekspansi Kredit. Economic Review No. 208, Juni 2007

Levine, R. 1997. Financial Development and Economic Growth: Views and Agenda. Journal of Economic Literature, 35, pp 688 - 726.

Maddala, G.S \& Kim, I.M. 1998. Unit Roots, Cointegration, and Structural Change. Cambridge: Cambridge Univ. Press.

Maski, G. 2010. Analisis Kausalitas antara Sektor Keuangan dan Pertumbuhan. Jurnal Ekonomi dan Pembangunan Indonesia, Vol. 10 No.2, pp 143-158.

Pindyck, R.S. \& D.L. Rubinfeld. 1998. Econometric Models and Economic Forecast, International ed. Singapore: Mc Graw Hill Book Co.

Ravallion S. \& S. Chen. 1997. What Can New Survey Data Tell Us about Recent Changes in Distribution and Poverty?. World Bank Economic Review, 11 (2), pp $357-382$

Siamat, D. 2005. Manajemen Lembaga Keuangan : Kebijakan Moneter dan Perbankan. Jakarta : FE UI

Shaw, S. Edward. 1973. Financial Deepening in Economic Development. Oxford: Oxford University Press

Stulz, R.M \& R. Williamson. 2003. Culture, Openness, and Finance. Journal of Financial Economics 70: pp 313-49.

Sukirno, S. 2007. Pengantar Makroekonomi. Jakarta: Raja Grafindo. 